\title{
STANDAR KELENGKAPAN FITUR E-LEARNING SUPPLY CHAIN MANAGEMENT PADA PRODUK BACKLOG MENGGUNAKAN METODOLOGI SCRUM
}

\author{
Ellin Asynari, Pajri Al Zukri, Nurbo Jatmiko \\ Sistem Informasi, Sains dan Teknologi, UIN Syarif Hidayatullah Jakarta, \\ Jl. Ir H. Juanda No.95, Cemp. Putih, Kec. Ciputat, Kota Tangerang Selatan, Banten 15412 \\ Email: ellin.asynari17@mhs.uinjkt.ac.id,pajri.alzukri17@mhs.uinjkt.ac.id, \\ nurbojatmiko@uinjkt.ac.id.
}

(Diterima: 9 Januari 2020,direvisi: 26 April 2020, disetujui: 1 Juli 2020 )

\begin{abstract}
The development of E-Learning features is a concern among developers. Making E-Learning features that meet the standards and in accordance with the needs of students and lecturers is one of the requirements in its application. The effectiveness of learning that is expected to be effective using $E$ Learning is still difficult to achieve due to various factors, one of which is lack of features in the system. Supply Chain Management (SCM) is a supply chain learning that has several series of activities, so it is important to ensure all chapters in SCM are mastered by students on time. We will compare several features of the 3 Learning Management System (LMS) applications. Among them are SEVIMA EdLink, Coursera, and Blackboard CourseSites. The results of this study will produce a standard set of features specific to SCM E-Learning to support learning effectiveness. The standard setting for features completeness will use the SCRUM framework in the product backlog. The results of the analysis are Prototype using Website-based MOODLE Tools.
\end{abstract}

Keywords : E-learning, MOODLE, LSM, SCM, SCRUM

\begin{abstract}
ABSTRAK
Pengembangan fitur E-Learning menjadi salah satu perhatian di kalangan pengembang. Pembuatan fitur E-Learning yang memenuhi standar dan sesuai dengan kebutuhan mahasiswa maupun dosen menjadi salah satu syarat dalam penerapannya. Efektifitas dari pembelajaran yang diharapkan efektif menggunakan E-Learning saat ini masih sulit dicapai karna berbagai faktor, salah satunya kurang lengkapnya fitur dalam sistem. Supply Chain Management (SCM) merupakan pembelajaran supply chain yang memiliki beberapa rangkaian kegiatan, maka dari itu penting memastikan semua bab dalam SCM di kuasai mahasiswa tepat waktu. Kami akan membandingkan beberapa fitur dari 3 aplikasi Learning Manajemen System (LMS). Diantaranya adalah SEVIMA EdLink, Coursera, dan Blackboard CourseSites. Hasil dari penelitian ini akan menghasilkan sebuah standar kelengkapan fitur yang dikhususkan pada E-Learning SCM untuk menunjang efektifitas pembelajaran. Penentuan standar kelengkapan fitur akan menggunakan framework SCRUM pada backlog product. Hasil analisa berupa Prototype menggunakan Tools MOODLE berbasis Website.
\end{abstract}

Kata Kunci: E-learning, MOODLE, LSM, SCM, SCRUM

\section{PENDAHULUAN}

Perkembangan ICT juga ikut mempengaruhi kegiatan pembelajaran menjadi lebih baik dalam beberapa hal, namun masih banyak penelitian sebelumnya yang menunjukkan bahwa ada beberapa hambatan dalam mengadopsi dan mengintegrasikan ICT dalam proses belajar mengajar [1]. Adanya kesenjangan antara pengetahuan ICT guru dengan siswa menjadikan penerapan LMS menjadi lebih lambat. Pelajar cenderung lebih menginginkan pembelajaran modern dan mandiri, sementara aplikasi dan fasilitas ICT yang tersedia masih kurang [2]. Penggunaan LMS dalam e-learning memberikan kemudahan karna akses yang mudah melalui website dengan penyimpanan cloud, serta beberapa keuntungan lain. Untuk memastikan implementasi LMS berhasil, penting untuk memahami faktorfaktor yang memengaruhi niat siswa terhadap LMS dan penggunaan aktualnya [3].

Ellin Asynari dkk : Standar Kelengkapan Fitur E-Learning Supply Chain Management Pada Produk Backlog Menggunakan Metodologi Scrum 
Sementara perkembangan terus terjadi di bidang e-learning, perkembangan tools e-learning di sekolah belum memadai, yaitu fasilitas yang kurang serta pengetahuan staff akademik (admin) masih membutuhkan banyak pelatihan dalam implementasinya [4]. Tingkat perguruan tinggi juga mengalami beberapa kesulitan dalam menerapkan E-Learning, ada beberapa gap yang dirasakan masih sulit untuk dicapai. Lima kategori besar adalah: gaya belajar dan tantangan budaya, tantangan e-learning pedagogis, tantangan teknologi, tantangan pelatihan teknis dan tantangan manajemen waktu [4]. Untuk menunjang efektifitas e-learning, maka hal utama yang dilakukan adalah menentukan features yang akan digunakan di dalam system, dimana pemilihan fitur yang masih menjadi salah satu hambatan pengembangan e-learning, system database juga menjadi factor penting yang masih sulit di atasi oleh pihak pengajar [5].

Heterogenitas pendekatan untuk organisasi e-learning pada platform LMS menyebabkan kesulitan dalam menilai kualitas e-learning [6]. Saat ini pembelajaran e-learning menggunakan prinsip agile. Pengembangan agile terdiri dari beberapa metodologi. Metodologi Agile paling populer termasuk Extreme Programming (XP), Scrum, Crystal, Dynamic Systems Development Method (DSDM), Feature-Driven Development (FDD), Pengembangan Lean dan sebagainya. Namun, Scrum telah lama dikenal sebagai metode Agile paling populer. Menurut Schwaber, Agile methodrum Scrum yang paling umum digunakan [7]. Salah satu artefak yang paling umum dalam proyek perangkat lunak kontemporer adalah product backlog yang terdiri dari cerita pengguna, bug, tugas atau item pekerjaan lainnya. Namun, sedikit penelitian yang menyelidiki bagaimana jaminan simpanan dihasilkan atau peran tepatnya yang dimainkannya dalam suatu proyek [8].

Untuk meningkatkan efektifitas pemahaman terhadap materi, penggunaan Agile Manifesto dan Scrum Framework dapat di implementasikan pada E-learning [9]. Dalam hal ini, Universitas menjadi produk owner, Dosen menjadi Scrum master, dan mahasiswa menjadi scrum team [10]. Dengan memanfaatkan Scrum framework pada pembelajaran, mahasiswa bertanggung jawab dalam menyelesaikan materi dengan cepat dan tepat sesuai dengan Produk backlog di awal rapat juga memberikan laporan perkembangan kepada Dosen disetiap rapat harian yang dilaksanakan sebelum sesi pembelajaran [11].

Dari permasalahan diatas, dapat disimpulkan bahwa perlu adanya standar kelengkapan fitur pada E-Learning. Maka dari itu kami akan mengembangkan standar kelengkapan fitur pada system ELearning dengan memanfaatkan Framework SCRUM yang terkhusus pada product backlog diharapkan mampu meningkatkan efektifitas pembelajaran. Salah satu aplikasi LMS yang paling banyak digunakan saat ini adalah Moodle cloud [9], yaitu open source platform pembelajaran cloudhosting yang menyediakan aplikasi untuk membangun situs pembelajaran online (E-learning) [12]. Ini berarti bahwa penggunaan LMS dalam lingkungan pembelajaran, seperti Moodle, memiliki harapan dari kedua belah pihak untuk mengintensifkan pengalaman belajar siswa [13]. Maka dari itu kemudian akan dibuat prototype menggunakan MOODLE.

\section{TINJAUAN PUSTAKA}

\section{E-Learning}

E-learning adalah suatu sistem atau konsep pendidikan yang memanfaatkan teknologi informasi dalam proses belajar mengajar. Dimana pembelajaran disusun dengan tujuan menggunakan sistem elektronik atau komputer sehingga mampu mendukung proses pembelajaran. Satu perubahan yang jelas adalah bahwa e-learning bukan lagi hal baru atau baru bagi sebagian besar organisasi dan institusi. Penggunaannya telah menyebar luas, dan ada banyak cara yang digunakan dalam kategori elearning [14].

Teori E-Learning terdiri oleh tiga komponen, e-learning dapat didefinisikan melalui kerangka kerja berbasis teori, yang berhubungan dengan "teknologi pembelajaran", "strategi pembelajaran" dan "model atau konstruksi Pedagogis". Tiga komponen ini mengatur berbagai hubungan di mana model desain elearning pedagogis didasarkan. mengintegrasikan berbagai dimensi, seperti cara orang belajar (cara terbuka / fleksibel), dengan strategi pembelajaran (kolaborasi, eksplorasi, pemecahan masalah) dan juga dengan teknologi. Kerangka tiga komponen, menyiratkan interaksi yang mempengaruhi lingkungan e-learning. Strategi instruksional adalah apa yang digunakan oleh instruktur atau sistem pembelajaran yang memfasilitasi pembelajaran, seperti kolaborasi, artikulasi, refleksi, permainan peran, eksplorasi, dan lain-lain. 


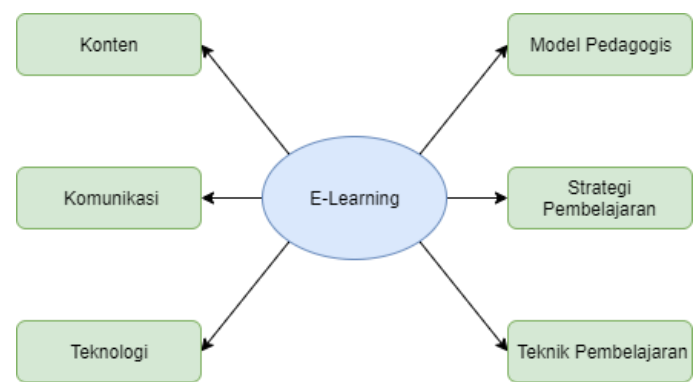

\section{Gambar 1. Konsep E-Learning Overlapping Perspektif [15]}

Karakteristik E-learning bersifat jaringan, yang membuatnya mampu memperbaiki secara cepat, menyimpan atau memunculkan kembali, mendistribusikan, dan sharing pembelajaran dan informasi. Karakteristik E-learning menurut [16] adalah:

1. Memanfaatkan jasa teknologi elektronik.

2. Memanfaatkan keunggulan komputer (digital media dan komputer networks)

3. Menggunakan bahan ajar yang bersifat mandiri (self learning materials) kemudian disimpan di komputer, sehingga dapat diakses oleh doesen dan mahasiswa kapan saja dan dimana saja.

4. Memanfaatkan jadwal pembelajaran, kurikulum, hasil kemajuan belajar, dan hal-hal yang berkaitan dengan administrasi pendidikan dapat dilihat setiap saat di komputer.

Fitur-fitur wajib yang ada pada e-learning dapat dilihat pada Google Classroom, yang merupakan salah satu e-learning yang paling banyak digunakan di berbagai kalangan [17] yaitu :

1. Kelas virtual

2. Penugasan

3. Terintegrasi

4. Berbagi tugas, dan

5. Mengirim tugas

Ada puluhan modalitas dalam kategori pembelajaran. Konten Anda akan membantu menentukan jenis pembelajaran apa yang ingin Anda gunakan, karena beberapa akan bekerja lebih baik untuk konten Anda daripada yang lain. Berikut ini adalah beberapa modalitas yang dianggap e-learning:

1. Modul atau kursus

2. Video dan gambar gerak

3. Gamifikasi

4. Pelatihan yang dipimpin oleh instruktur virtual (VILT), seperti WebEx atau webinar

5. MOOCs

6. Forum sosial

7. Podcast

8. Polling waktu nyata

\section{SCRUM Backlog}

Scrum adalah kerangka kerja yang memfasilitasi proses penemuan yang terorganisir. Ini mengatur orang ke dalam tim yang dapat menemukan dan menangani hal-hal yang tidak terduga. Mereka belajar sambil berjalan. Pada akhirnya, mereka menciptakan produk dengan menemukan solusi untuk tantangan tak terduga yang mereka temui dalam perjalanan mereka untuk memberikan hasil yang diinginkan. Prinsip-prinsip scrum telah banyak digunakan di berbagai bidang, salah satunya untuk meningkatkan efektifitas dalam pembelajaran. 


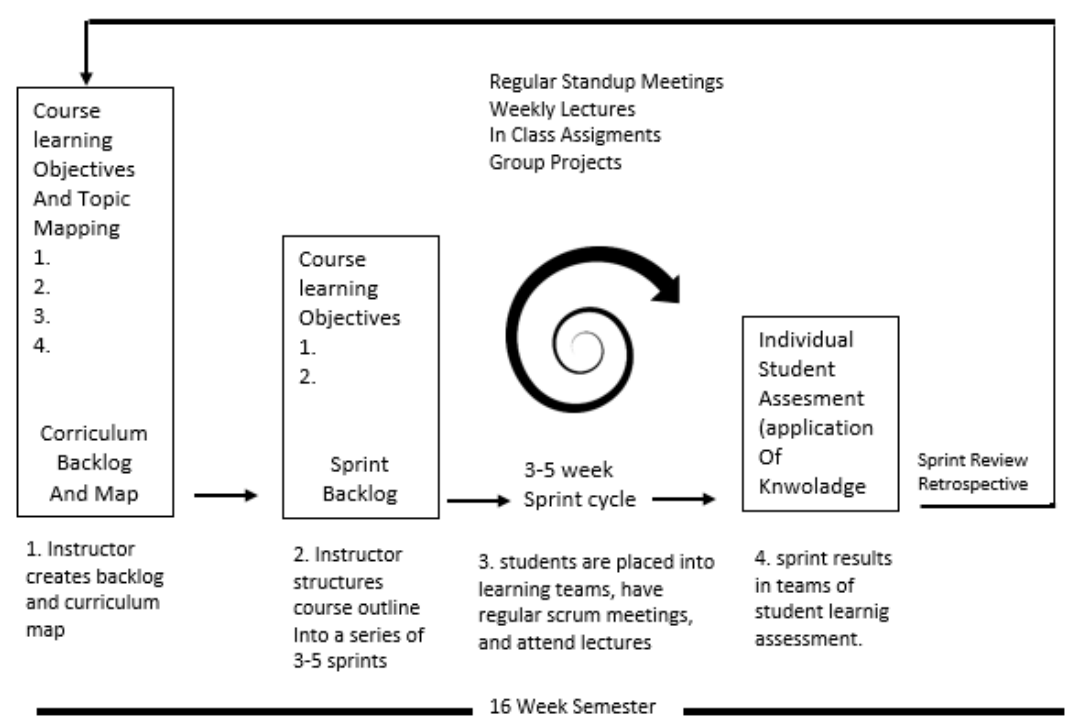

Gambar 2. Scrum Principle In Education [18]

Gambar diatas menjelaskan tentang bagaimana mengadaptasi kerangka kerja SCRUM ke ruang kelas dan menggunakan beberapa sprint untuk mengajarkan topik-topik IS yang kompleks. Tujuan dan konsep pembelajaran inti dipecah menjadi sprint yang lebih kecil. Yang membahas bagaimana teknik SCRUM seperti stand up harian, dan sprint retrospektif dapat menjadi alat yang berguna di kelas. Berdasarkan [18], pendekatan ini membantu siswa merangkul konsep-konsep kompleks, menumbuhkan kolaborasi, dan membantu instruktur melacak kinerja siswa terhadap tujuan pembelajaran. Dimana, scrum merupakan salah satu Agile Development Metodology yang berfokus pada kerja sama tim dan product backlog [19].

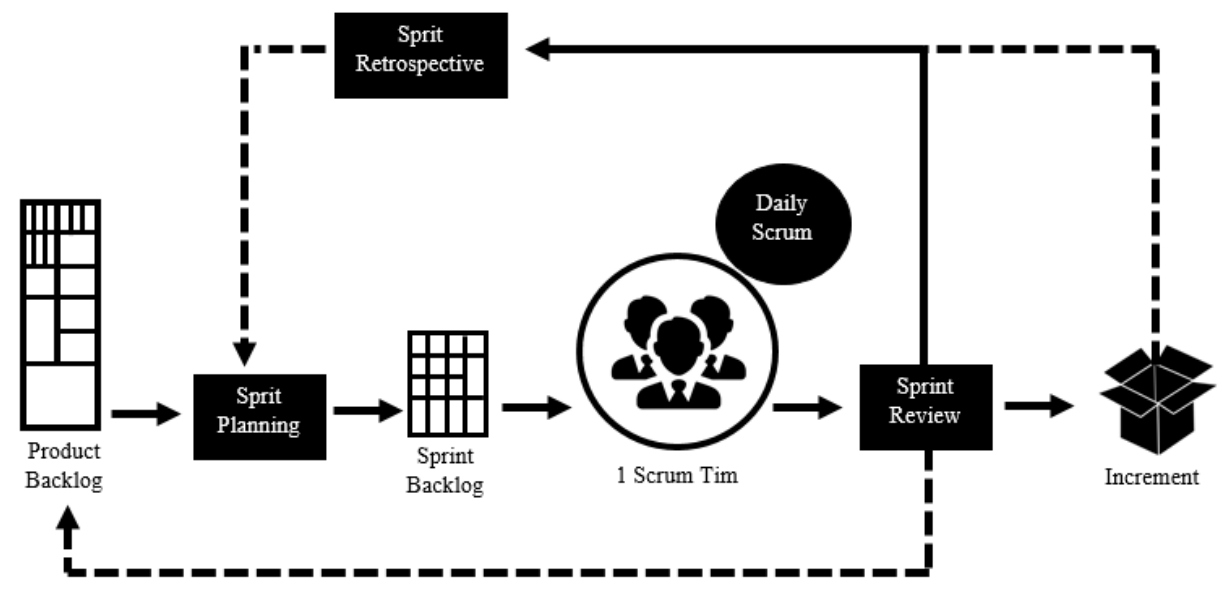

Gambar 3. SCRUM Framework [20]

Product Backlog adalah sistematis antrian fitur yang menjadi requirements dari pemilik produk [21]. Product Backlog dapat diartikan dengan beberapa point :

1. To-Do-List yang Wajib Dikerjakan Berurutan. 


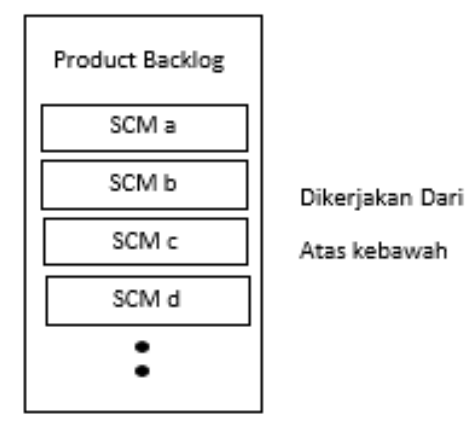

\section{Gambar 4. Urutan Penempatan Fitur Pada Product Backlog}

2. Dapat berubah sepanjang waktu.
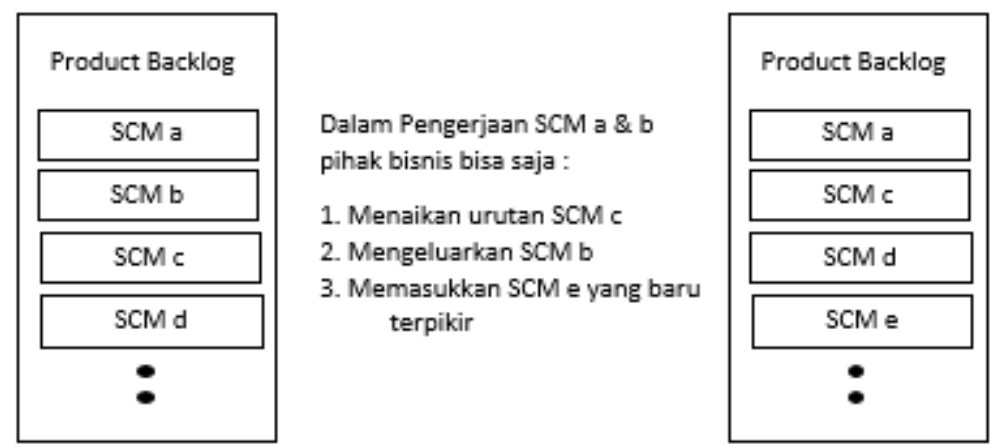

\section{Gambar 5. Urutan Fitur Mengalami Perubahan Sesuai Dengan Kebutuhan User}

3. Ditulis menggunakan Bahasa bisnis.
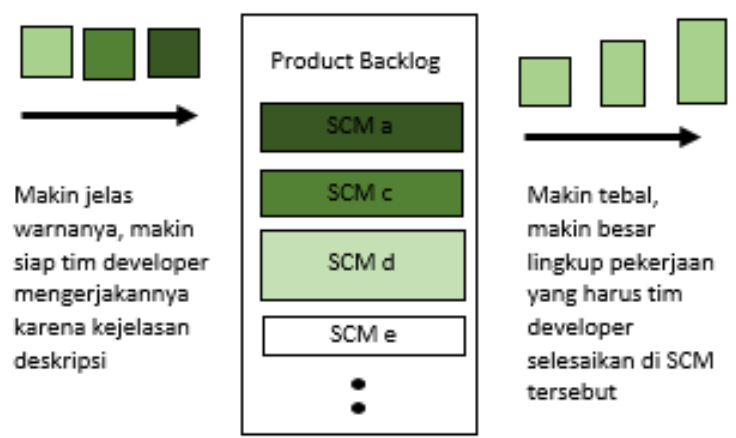

\section{Gambar 6. Product Backlog Menggunakan Bahasa Bisnis}

\section{Supply Chain Management (SCM)}

Objek SCM jelas adalah rantai pasokan yang mewakili “... jaringan organisasi yang terlibat, melalui hubungan hulu dan hilir, dalam berbagai proses dan kegiatan yang menghasilkan nilai dalam bentuk produk dan layanan di tangan para konsumen akhir". Dalam arti luas, rantai pasokan terdiri dari dua atau lebih organisasi yang dipisahkan secara hukum, dihubungkan oleh materi, informasi, dan aliran keuangan. Organisasi-organisasi ini dapat berupa perusahaan yang memproduksi suku cadang, komponen dan produk akhir, penyedia layanan logistik dan bahkan pelanggan (akhir) itu sendiri. Jadi, definisi rantai pasokan di atas juga memasukkan kelompok sasaran - pelanggan akhir [22].

Rantai pasokan terdiri dari semua pihak yang terlibat, secara langsung atau tidak langsung, dalam memenuhi permintaan pelanggan. Rantai pasokan tidak hanya mencakup produsen dan pemasok, tetapi juga pengangkut, gudang, pengecer, dan bahkan pelanggan sendiri. Dalam setiap 
organisasi, seperti produsen, rantai pasokan mencakup semua fungsi yang terlibat dalam menerima dan mengisi permintaan pelanggan. Fungsi-fungsi ini termasuk, tetapi tidak terbatas pada, pengembangan produk baru, pemasaran, operasi, distribusi, keuangan, dan layanan pelanggan.

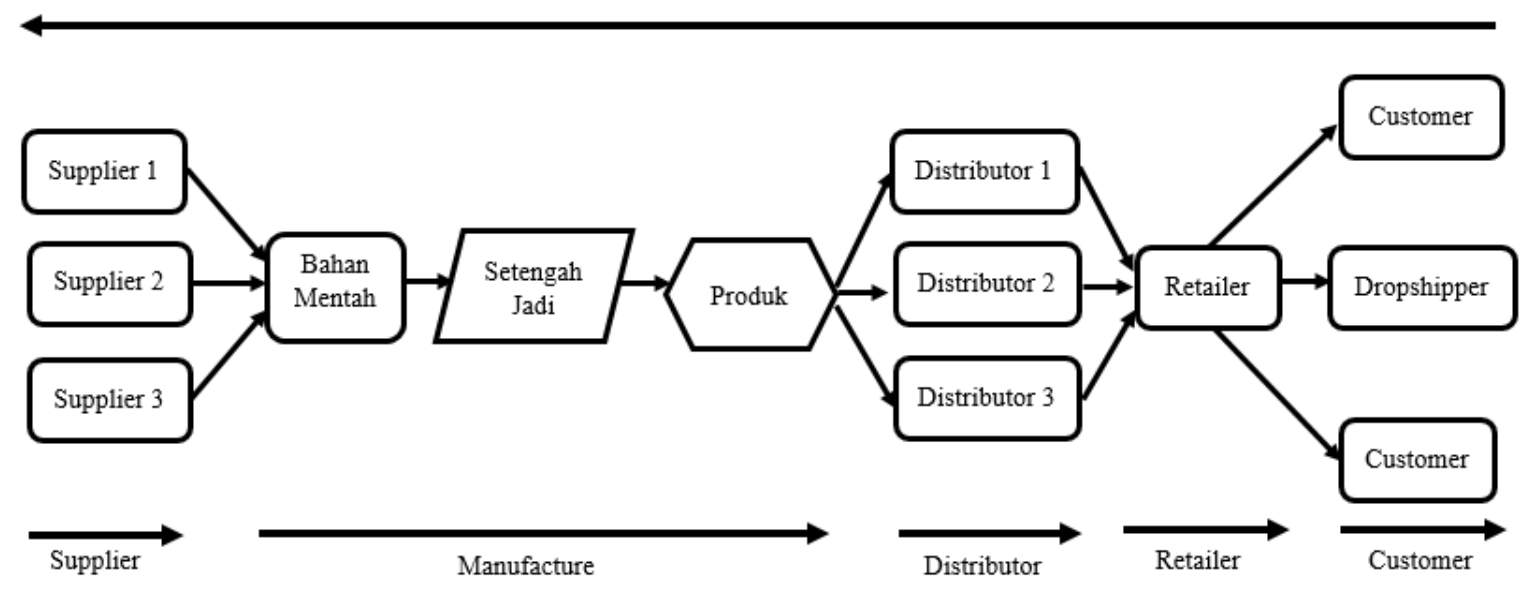

\section{Gambar 7. Supply Chain Cycle}

\section{Learning Management System (LMS)}

LMS adalah salah satu alat teknologi informasi yang muncul yang memfasilitasi e-learning dan menyediakan pembelajaran tanpa kendala waktu dan tempat. Ini adalah sistem berbasis web yang memungkinkan instruktur dan siswa untuk berinteraksi melalui web dan berbagi informasi. Berbagai lembaga pendidikan telah menginvestasikan banyak sumber daya untuk mendukung kualitas proses belajar mengajar [3].

LMS telah menjadi tools utama untuk memberikan dan mengelola kursus-kursus e-learning di bidang pendidikan, bisnis, pemerintahan dan pengaturan pembelajaran kejuruan. Sejak pertengahan tahun sembilan puluhan ada sejumlah besar LMS di pasar dengan beragam fitur. Meningkatnya kompleksitas platform ini menjadikan evaluasi LMS proses yang sulit dan berat yang membutuhkan banyak pengetahuan, waktu, dan upaya [23]

Peran LMS bervariasi tergantung pada tujuan organisasi, strategi pelatihan online, dan hasil yang diinginkan. Namun, penggunaan paling umum untuk perangkat lunak LMS adalah untuk menyebarkan dan melacak inisiatif pelatihan online. Biasanya, aset diunggah ke Sistem Manajemen Pembelajaran, yang membuatnya mudah diakses oleh pelajar jarak jauh. Dalam beberapa kasus, LMS bahkan mungkin memiliki alat authoring e-learning internal yang memungkinkan Anda untuk mengembangkan materi pelatihan online tanpa perangkat lunak pihak ketiga tambahan [24].

\section{MOODLE}

MOODLE merupakan salah satu platform LMS E-Learning berbasis website yang dapat di akses pada https://Moodle.org/ dan merupakan aplikasi LMS open source. Berikut adalah beberapa manfaat menggunakan MOODLE menurut [25][26]:

1. Mereka mendapatkan kursus dan topik, perpustakaan virtual yang dapat mereka akses kapan saja, sesuai dengan ketersediaan studi mereka

2. Mereka dapat berkolaborasi dengan kolega mereka dalam melakukan pekerjaan rumah

3. Karena mereka terbiasa dengan lingkungan elektronik, mereka menemukan metode pembelajaran ini mudah, di tangan

4. Mereka dapat membuat informasi dan mempostingnya di forum atau blog

5. Mereka dapat menghubungi profesor secara langsung

6. Penilaian online lebih objektif daripada yang tradisional

7. Penilaian diri dapat dengan mudah diselesaikan 
Fitur-fitur yang di sediakan Moodle adalah sebagai berikut :

1. Assignment submission

2. Forum diskusi

3. Unduh arsip

4. Peringkat

5. Chat

6. Kalender online

7. Berita

8. Kuis online

9. Wiki

Sedangkan infrastruktur Moodle yaitu :

1. aktifitas (termasuk permainan matematika dan kata)

2. jenis-jenis sumber daya

3. jenis-jenis pertanyaan (pilihan berganda, benar dan salah, mengisi titik-titik, dll)

4. jenis-jenis pengisian data (untuk aktifitas database)

5. tema bergambar

6. metode autentikasi (yang membutuhkan akses menggunakan username dan password)

7. metode pengambilan pembelajaran

8. penyaring konten

\section{METODE PENELITIAN}

Metode penelitian menggunakan metode kualitatif [27], dengan strategi Research and Development (R\&D). Pengembangan system menggunakan Metodologi Agile dengan menerapkan framework Scrum pada pengembangan sistem pembelajaran, begitu juga dalam produk backlog dengan menentukan fitur yang sesuai. Objek penelitian adalah Pembelajaran SCM. Sumber data berasal dari jurnal dan penelitian terdahulu yang terkait dengan permasalahan. Dan metode pengumpulan data dengan observasi dan studi literatur. Pembuatan prototype E-Learning menggunakan LMS MOODLE berbasis website.

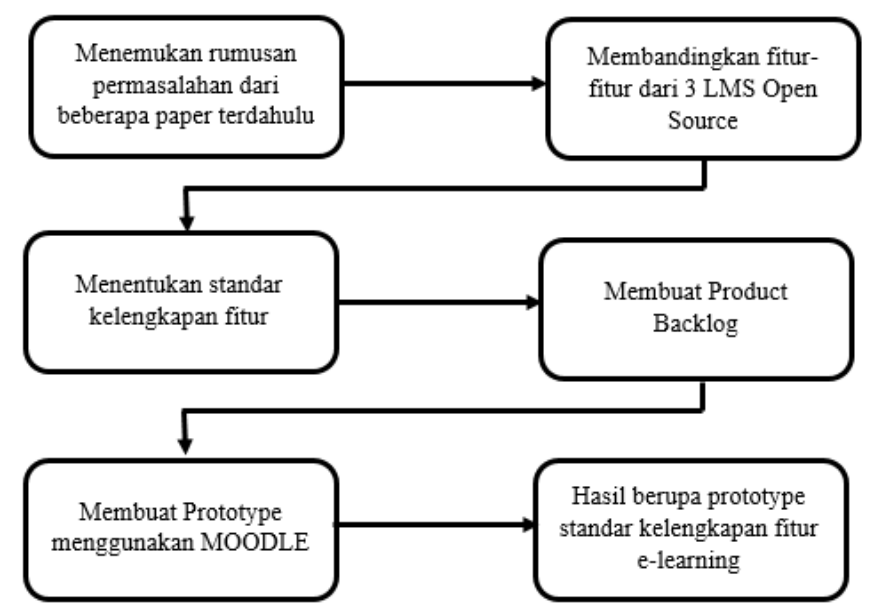

\section{Gambar 8. Tahapan Penelitian}

Penentuan rumusan masalah dilakukan dengan mempelajari beberapa penelitian terkait sebelumnya, yaitu mengenai e-learning dan fitur-fitur yang biasanya terdapat dalam e-learning. Ditemukan beberapa penelitian sebelumnya yang mengemukakan bahwa beberapa fitur dalam elearning belum bisa sepenuhnya dapat memenuhi kebutuhan pembelajaran mahasiswa. Salah satu penelitian juga mengemukakan sebuah teori tentang bagaimana SCRUM dapat digunakan di dunia Pendidikan [18]. Membandingkan 3 LMS open source yaitu SEVIMA EdLink, Coursera, Blackboard CourseSites. Masing-masing memiliki fitur yang berbeda, kemudian fitur yang berbeda akan kami satukan dan membentuk sebuah standar kelengkapan fitur e-learning. Setelah mendapatkan standar kelengkapan fitur, kami akan menerapkan prinsip Scrum product backlog untuk membuat susunan 
topik mata kuliah SCM. Pembuatan prototype dilakukan dengan memanfaatkan tools MOODLE. Yang memberikan fitur untuk membuat sebuah portal e-learning sesuai dengan kebutuhan pengembang secara open source.

\section{HASIL DAN PEMBAHASAN}

\section{Menentukan Standar Kelengkapan Fitur}

Untuk menemukan standar kelengkapan fitur-fitur pada pengembangan e-learning, kami membandingkan beberapa fitur dari 3 LMS open source, berikut adalah fitur-fitur yang ada di setiap LMS.

\section{SEVIMA EdLink}

Sevima EdLink merupakan salah satu platform LMS yang menyediakan e-learning gratis. adalah aplikasi berbasis android yang dikhususkan untuk dunia pendidikan dalam membantu dosen/guru menghemat waktu, menjaga kelas tetap teratur, dan meningkatkan komunikasi dengan mahasiswa.

a. Fitur Forum Diskusi dan Kelas

Membuat forum diskusi ataupun kelas dan didalam forum anda dapat terhubung dengan temanteman, mahasiswa (murid) atau dosen (guru) anda. Berbagi informasi, data, acara, survey, media dll menjadi lebih mudah. Forum dapat dibuat publik dan privat. (Forum kelas hanya dapat dibuat oleh dosen/guru)

b. Fitur Berbagi

Pengajar maupun pengajar dapat berbagi jenis data/file apa pun dapat anda bagikan dengan teman-teman dalam forum yang sama.

c. Fitur Tugas dalam Kelas

Dosen/guru dapat membuat tugas di dalam forum kelas. Dosen dapat melihat semua jawaban dan memberikan penilaian pada jawaban-jawaban tersebut. Di akhir mahasiswa dapat melihat semua jawaban temannya. Fitur ini membantu dosen/guru untuk melihat bagaimana pemahaman mahasiswa/murid terhadap materi kuliah/pelajaran. Dari sisi mahasiswa/murid, fitur ini membantu mereka untuk menambah referensi belajar dari jawaban teman-temannya.

d. Fitur Pesan Pribadi

Siapa saja dapat mengirim pesan pribadi pada temen atau dosen/guru anda yang berada pada forum yang sama.

e. Fitur Info, Acara dan Survey

Dalam forum kita dapat membuat post info untuk menginformasikan segala sesuatu kepada teman dalam forum tersebut, membuat post acara untuk mengagendakan suatu acara untuk forum tersebut, dan membuat post survey untuk membuat survey dalam forum tersebut.

\section{Coursera}

Coursera adalah perusahaan teknologi pendidikan Amerika Utara yang didirikan oleh Profesor Ilmu Komputer Andrew Ng dan Daphne Koller. Berkantor pusat di kota Mountain View, California, AS , Coursera menawarkan kursus online di berbagai bidang minat, semuanya $100 \%$ online dan dengan sertifikasi.

Berikut adalah fitur-fitur yang terdapat pada Coursera :

a. Fitur memilih kelas kursus

Fitur ini memungkinkan pelajar untuk memilih apa tujuannya menggunakan coursera, kemudian akan diberikan rekomendasi kelas-kelas yang sesuai dengan keinginan.

b. Fitur enroll

Fitur ini digunakan untuk masuk kedalam komunitas kelas, dan memualai pembelajaran. Ada beberapa pilihan enrolled yang gratis dan berbayar. Untuk yang gratis bias menggunakan pilihan audit.

c. List overview

Melihat apa saja yang akan dipelajari beberapa minggu ke depan. Bentuknya seperti product backlog, ada kategori-kategori yang harus di penuhi selama seminggu.

d. Fitur grades

Fitur ini untuk melihat hasil (nilai) yang pelajar dapat di setiap session.

e. Fitur notes

Berupa catatan-catatan pelajar di setiap session. 


\section{f. Fitur diskusi}

Merupakan fitur membagikan pertanyaan tambahan dan bantuan jawaban dari setiap permasalahan yang ada di setiap session.

\section{Blackboard Coursites}

CourseSites oleh Blackboard memberi setiap instruktur alat yang paling kuat untuk memperluas ruang kelas mereka secara online, meningkatkan produktivitas dan efisiensi, dan meningkatkan keterlibatan dan prestasi siswa. Alat-alat ini gratis dan semuanya terletak di satu tempat. Berikut adalah beberapa fitur yang tersedia dari Blackboard Coursites :

a) Announcement: Ini biasanya merupakan titik masuk untuk kelas. Posting Pengumuman kepada siswa di sini. Untuk setiap Pengumuman Anda akan memiliki opsi untuk mengirim email kepada siswa juga.

b) Course Silabus: Semua kelas diwajibkan, minimal, untuk mengirim silabus dan menggunakan alat Silabus.

c) Getting Started, and Course Content: Ini adalah dua Area Konten default. Perhatikan bujur sangkar di sebelah masing-masing. Ini mengindikasikan awalnya kosong. Area Konten Kosong tidak akan ditampilkan kepada siswa, jadi tidak ada tautan ini yang akan ditampilkan hingga Anda memposting sesuatu di dalamnya. Bergantung pada kebutuhan atau kelas Anda, Anda mungkin atau mungkin tidak menggunakan semua Area Konten ini. Anda juga memiliki opsi untuk membuat Area Konten baru jika struktur kelas Anda akan mendapat manfaat. Akses Tamu ke Area Konten: "Tamu" adalah pengunjung kelas Anda yang tidak termasuk dalam daftar kelas Anda. Situs kursus default memungkinkan akses tamu ke Pengumuman, Silabus dan Memulai tetapi tidak ke Konten Kursus. Jika Anda membuat Area Konten baru maka itu juga akan diatur ke "Tolak Tamu", tetapi ini dapat diubah menggunakan menu drop-down di sebelah kanan tautan Menu Kursus. Tombol untuk menu drop-down hanya muncul ketika mouse melewati item menu tertentu. Para tamu dibatasi dari mengunjungi daerah Diskusi dan Daftar Kelas di mana informasi siswa terlihat.

d) Discussion (Diskusi Board), WebMeeting, dan Arsip WebMeeting: Semua ini awalnya disembunyikan seperti yang ditunjukkan oleh kotak dengan garis miring di sebelah tautan. Untuk mengaktifkan penggunaan alat-alat ini oleh siswa: arahkan mouse ke daftar menu kemudian klik pada lingkaran dengan panah di sebelah kanan tautan (2). Dari menu yang dihasilkan pilih "Tampilkan Tautan".

e) My Grades : ini adalah buku nilai siswa. Awalnya disembunyikan secara default. Sekali lagi gunakan menu drop-down untuk menunjukkannya. Mereka hanya melihat nilai mereka sendiri di sini. Instruktur mengakses buku nilai melalui Panel Kontrol di bawah Menu Kursus.

f) Class list : tautan ke daftar kelas UAS Online

Setelah menemukan fitur-fitur yang ada dari masing-masing LMS. Kemudian semua fitur di satukan. Tabel 1 menjelaskan bahwa semua fitur tersebut masih tidak terdapat di antara LMS.

Tabel 1. Fitur-Fitur pada LMS

\section{Learning Management System}

\begin{tabular}{|c|c|c|c|}
\hline Fitur-fitur & SEVIMA EdLink & Coursera & $\begin{array}{l}\text { Blackboard } \\
\text { CourseSites }\end{array}$ \\
\hline Kelas & $\overline{\text { Ada }}$ & Ada & Ada \\
\hline Diskusi & Ada & Ada & Ada \\
\hline Berbagi Dokumen & Ada & Tidak ada & Tidak ada \\
\hline Tugas & Ada & Ada & Ada \\
\hline Pesan & Ada & Tidak ada & Tidak ada \\
\hline Info & Ada & Tidak ada & Tidak ada \\
\hline Overview/Silabus & Tidak ada & Ada & Ada \\
\hline Hasil Penilaian & Tidak ada & Ada & Ada \\
\hline Pengumuman & Tidak ada & Tidak ada & Ada \\
\hline Bantuan & Tidak ada & Ada & Ada \\
\hline
\end{tabular}

\section{Pembuatan Produk Backlog}

Ellin Asynari dkk : Standar Kelengkapan Fitur E-Learning Supply Chain Management Pada Produk Backlog Menggunakan Metodologi Scrum 
Setelah menentukan standar kelengkapan fitur, selanjutnya dibuat product backlog dari ELearning SCM. Adapun product backlog untuk E-Learning SCM diperlihatkan di tabel 2 berikut.

\section{Tabel 2. Product Backlog E-learning SCM}

\begin{tabular}{ll}
\hline No & Product Backlog \\
\hline $\mathbf{1}$ & Kelas \\
$\mathbf{2}$ & Diskusi \\
$\mathbf{3}$ & Tugas \\
$\mathbf{4}$ & Silabus \\
$\mathbf{5}$ & Hasi Penilaian \\
$\mathbf{6}$ & Bantuan \\
$\mathbf{7}$ & Berbagi Dokumen \\
$\mathbf{8}$ & Pesan \\
$\mathbf{9}$ & Info \\
$\mathbf{1 0}$ & Pengumuman
\end{tabular}

\section{Pembuatan Prototype}

Pembuatan prototype e-learning berbasis Moodle memerlukan beberapa tahapan. Setiap tahapan dikerjakan menggunakan pengembangan scrum backlog. Fitur-fitur di dalamnya di seusaikan dengan hasil dari Tabel 1 dengan melihat seberapa penting dan seringnya fitur tersebut digunakan di beberapa LMS. Sebelum itu, dilakukan instalasi Moodle terlebih dahulu. Ada dua cara dalam menginstal aplikasi moodle, yaitu instalasi secara daring (online) dan atau instalasi secara luring (offline). Instalasi secara daring (online) adalah instalasi atau pemasangan yang dilakukan dengan terhubung langsung dengan internet. Sementara instalasi secara luring (offline) adalah instalasi atau pemasangan yang dilakukan tanpa terhubung dengan internet. Keduanya memiliki langkah atau prosedur yang berbeda. Berikut adalah tahapan instalasi Moodle. 1)Apache, MySQL/MariaDB dan PHP, untuk pengguna windows dapat menggunakan XAMPP. Untuk versi-nya menyesuaikan dengan System Requirement dari versi moodle yang digunakan; 2)File Moodle, dapat di download di situs resminya moodle.org; 3)Extract file yang telah di install; 4)Copy folder Moodle pada localhost; 5)Membuat database pada PHP My Admin; 6)Selanjutnya melakukan instalasi Moodle sampai selesai;

a. Tampilan Log In

Berisi form login. Terdiri dari username, password, dan remember me. Terdapat tombol masuk, dan masuk sebagai tamu untuk yang belum memiliki akun terdaftar. Tampilan menu login dapat dilihat pada Gambar 9.
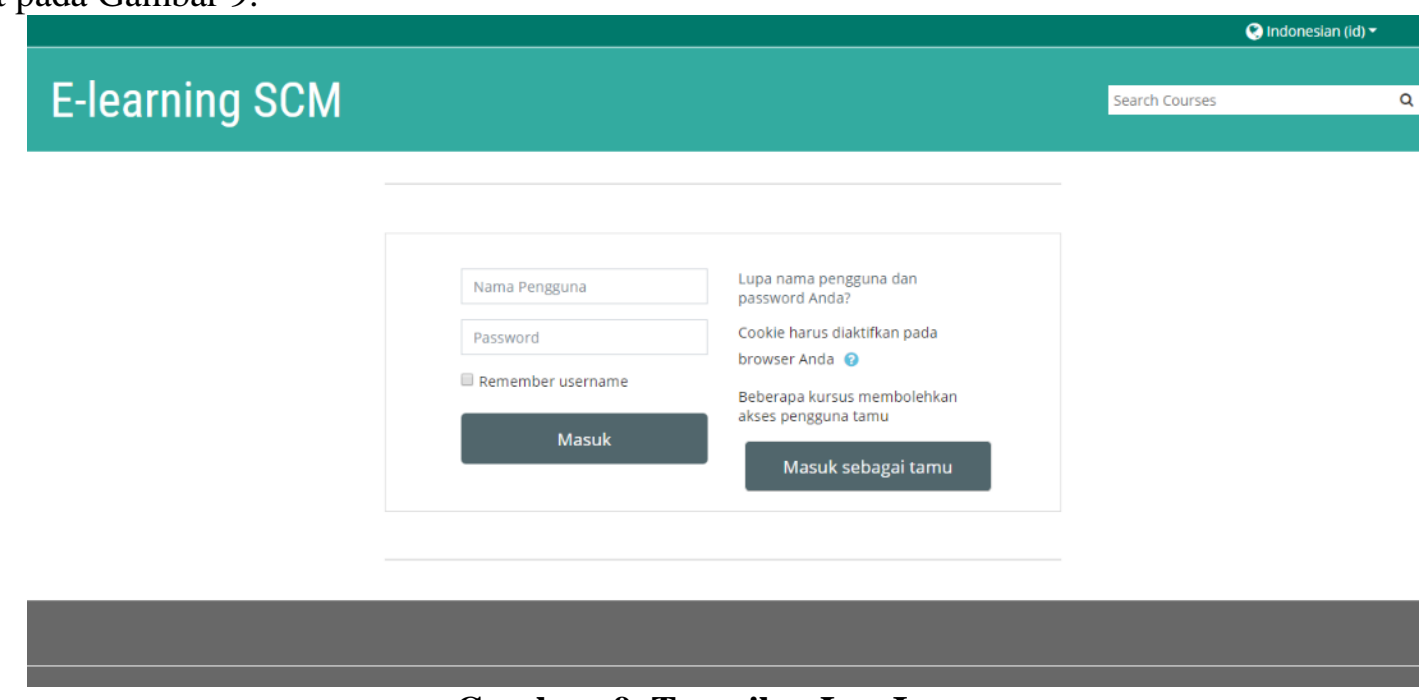

Gambar 9. Tampilan Log In 
b. Tampilan Home

Berisi tampilan utama yang terdiri dari menu atas, notifikasi pengumuman, diskusi umum, tampilan kartu course, search. Tampilan menu utama/home dapat dilihat pada Gambar 10.

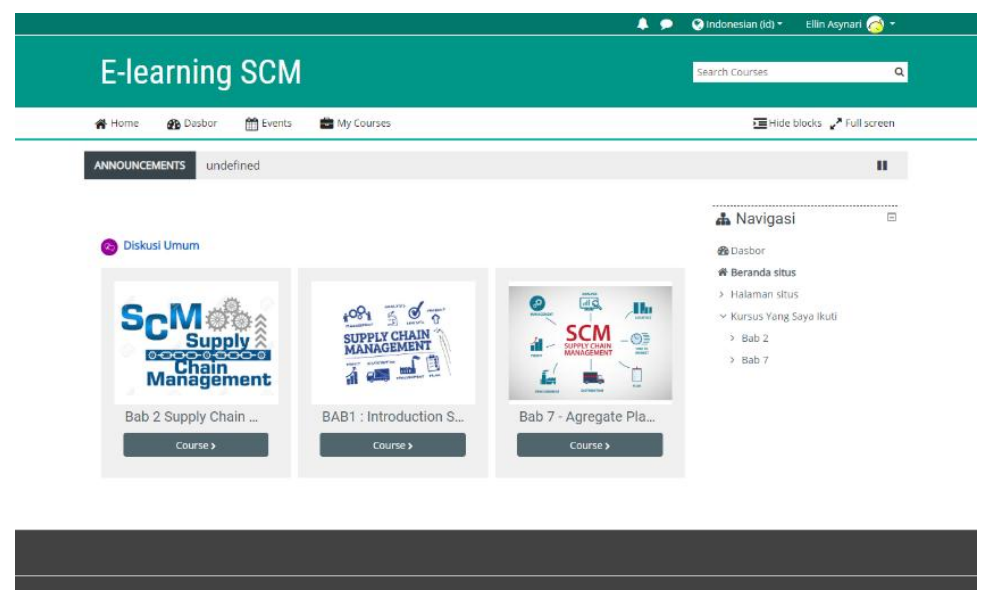

c. Tampilan Kelas

\section{Gambar 10. Tampilan Home}

Tampilan kelas berisi daftar-daftar kelas yang di ikuti oleh mahasiswa. Terdapat juga diskusi umum di setiap kelas. Pengumuman tugas, dan pengumuman pergantian jadwal. Tampilan kelas dapat dilihat pada Gambar 11.

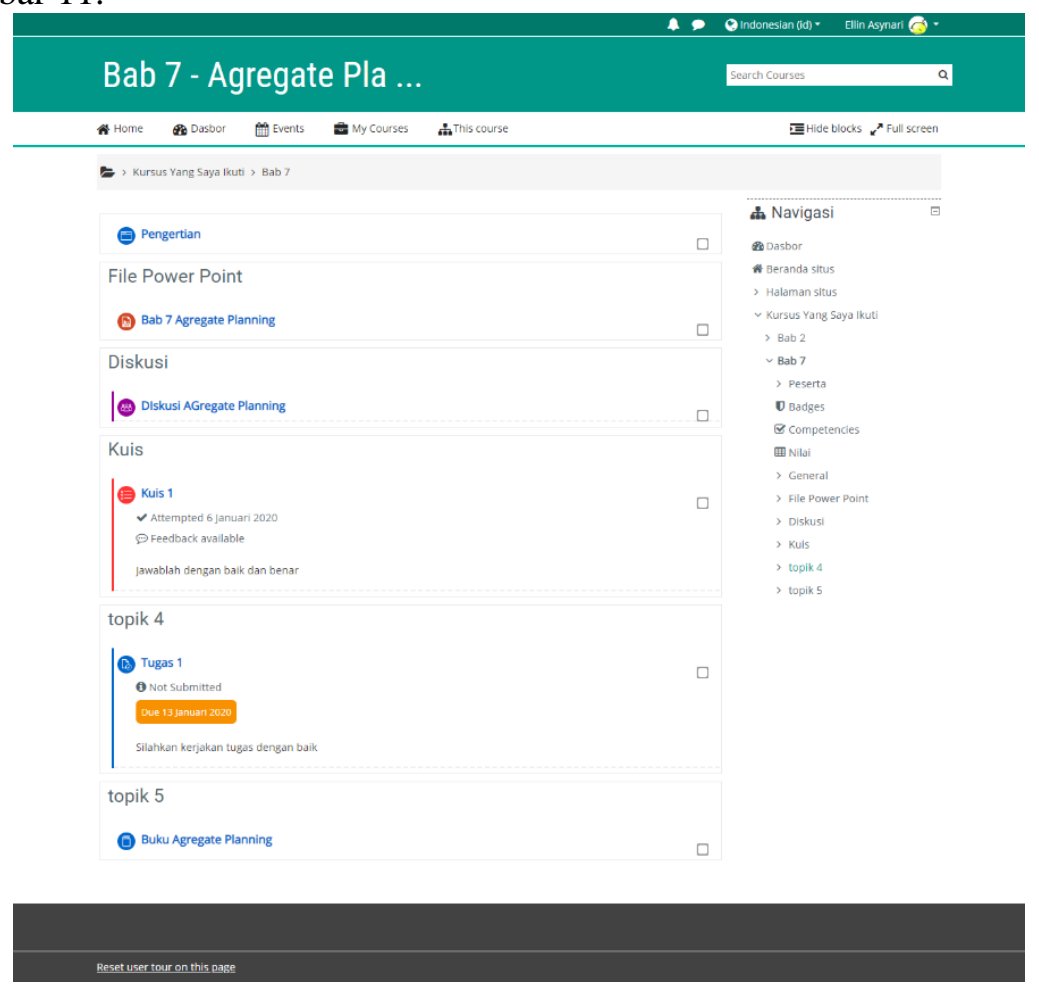

\section{Gambar 11. Tampilan Kelas}

d. Tampilan Submission Tugas

Tampilan submission tugas berisi form untuk mengupload dokumen tugas. Tipe-tipe tugas yang dapat diupload adalah word, pdf, gdoc, dll. Tampilan submission tugas dapat dilihat pada Gambar 12. 


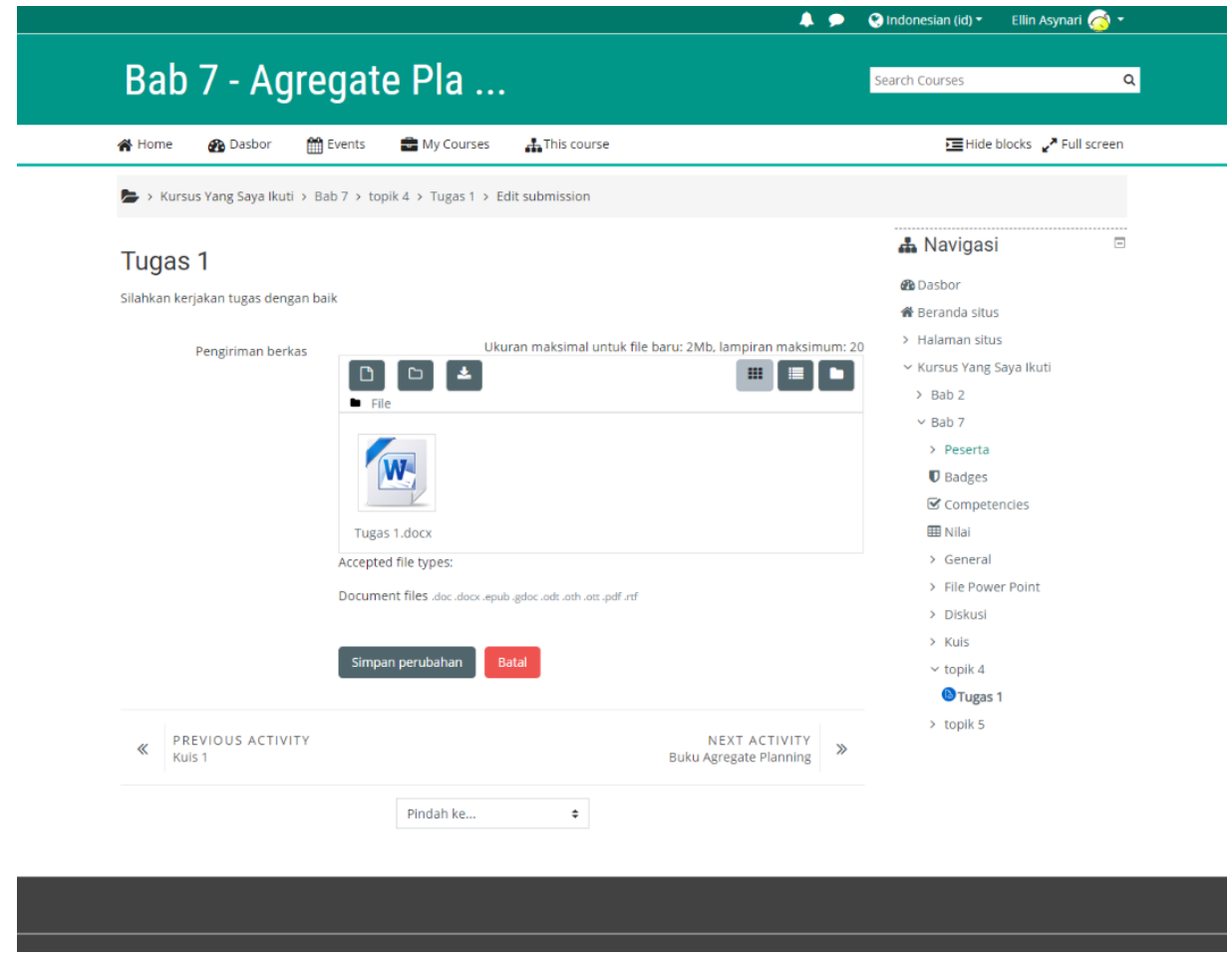

Gambar 12. Tampilan Submission Tugas

e. Tampilan Status Submission

Tampilan status submission terdiri dari form status upload tugas. Terdiri dari submission status, penilaian, tanggal, waktu, modifikasi, dan nama berkas. Tampilan status submission dapat dilihat pada Gambar 13.

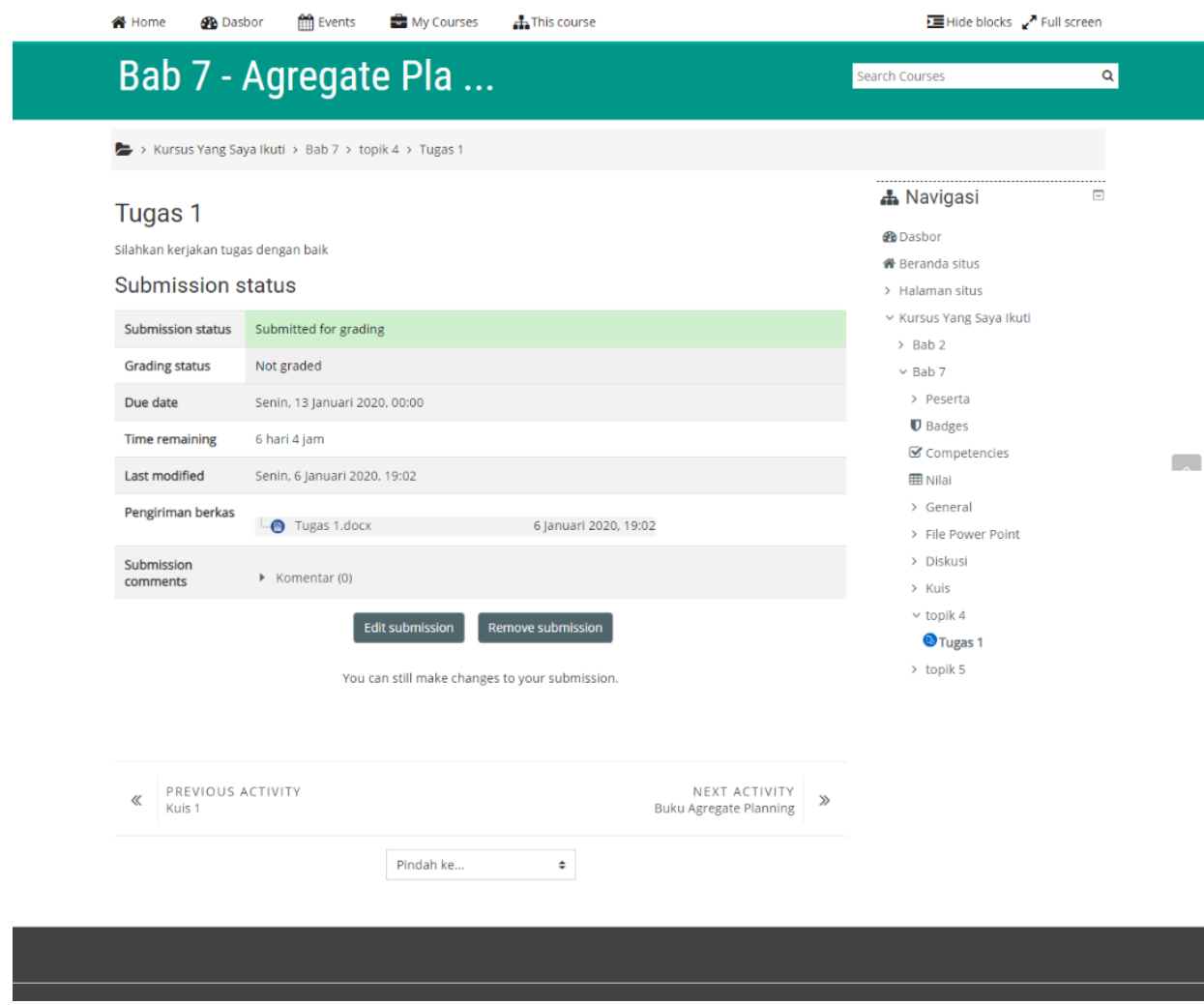

\section{Gambar 13. Tampilan Status Submission}

\section{f. Tampilan Materi}

Ellin Asynari dkk : Standar Kelengkapan Fitur E-Learning Supply Chain Management Pada Produk Backlog Menggunakan Metodologi Scrum 
Tampilan materi menunjukkan tulisan isi materi yang telah di upload atau dibuat dosen/guru. Tampilan materi dapat dilihat pada Gambar 14.

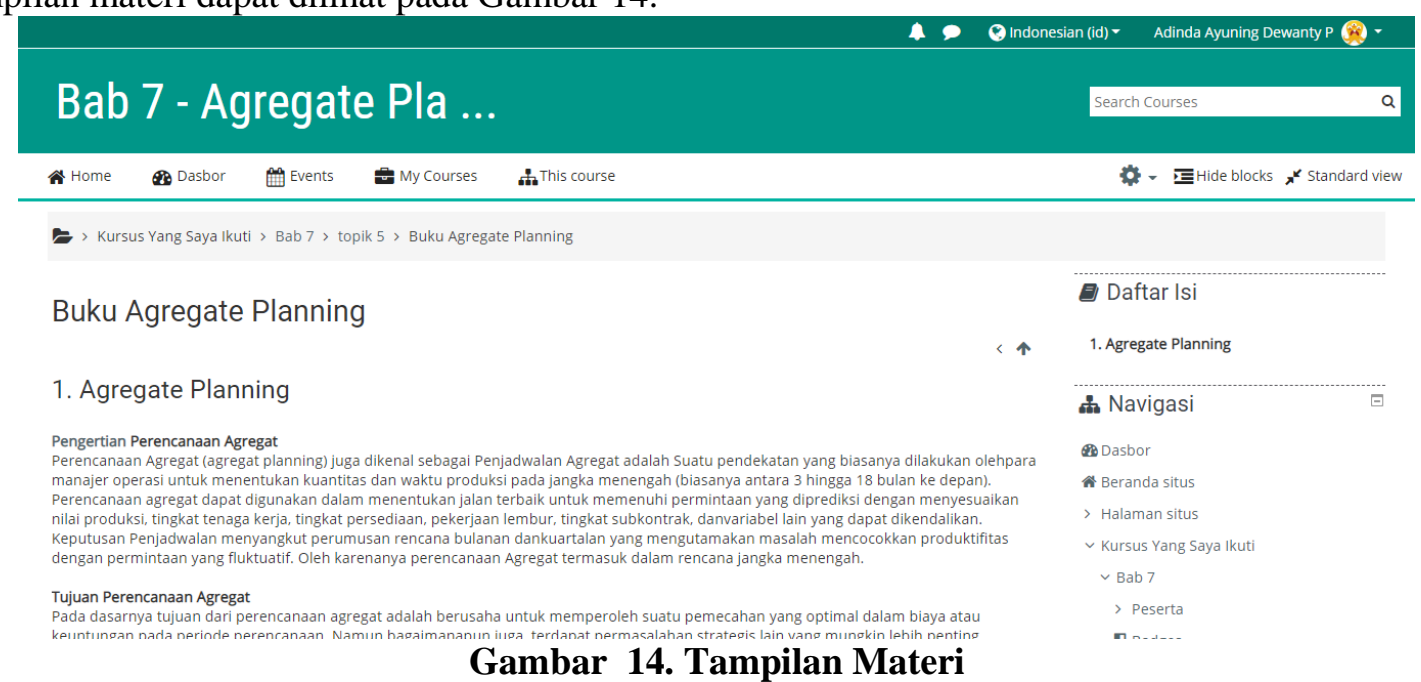

g. Tampilan Diskusi

Tampilan diskusi berisi tugas diskusi yang dibuat dosen/guru untuk di diskusikan mahasiswa. Tampilan diskusi dapat dilihat pada Gambar 15.

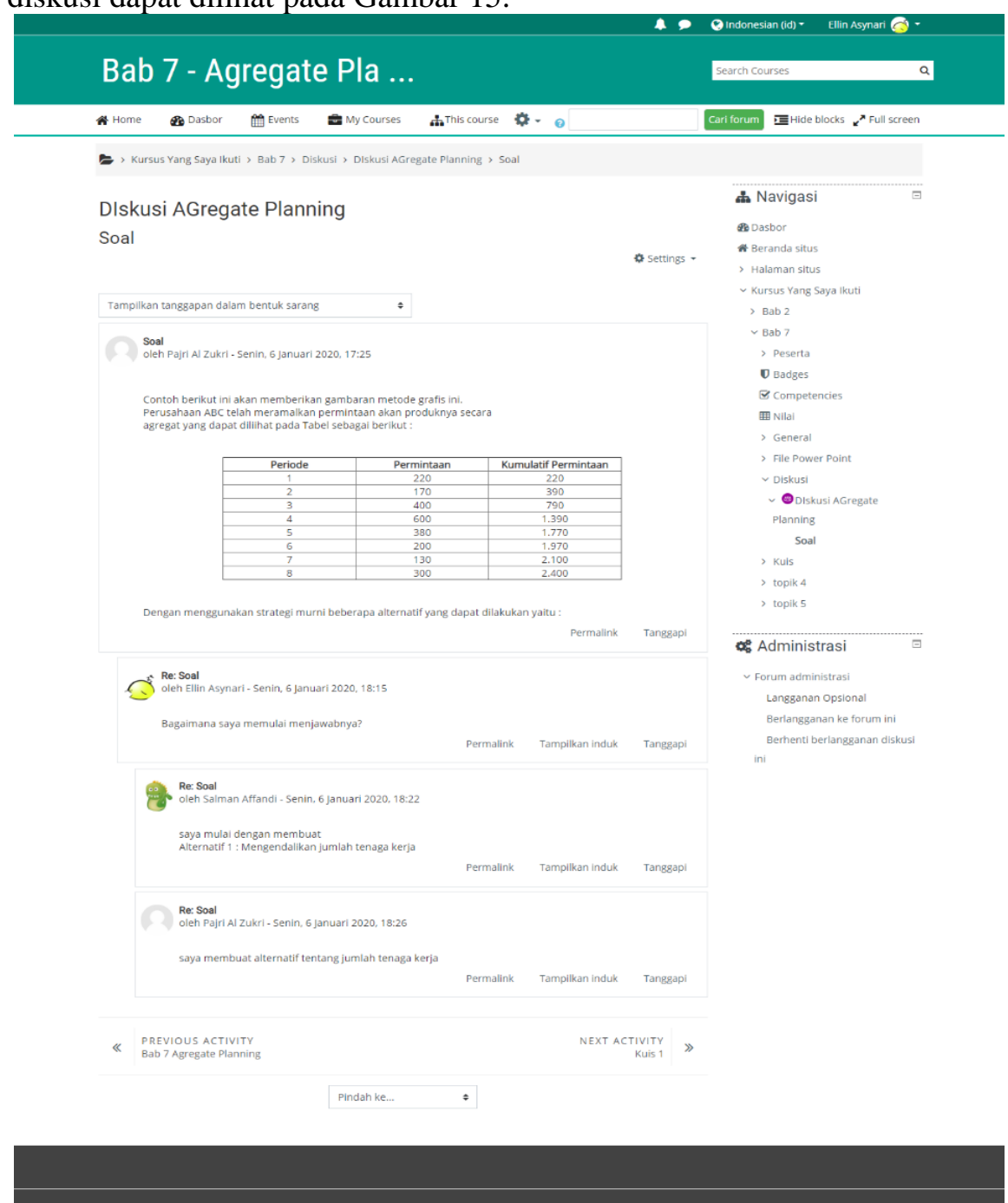

\section{Gambar 15 Tampilan Diskusi}

Ellin Asynari dkk : Standar Kelengkapan Fitur E-Learning Supply Chain Management Pada Produk Backlog Menggunakan Metodologi Scrum 
h. Tampilan Quiz

Tampilan Quiz merupakan tampilan tugas yang di buat dosen/guru. Terdapat tampilan komentar dibawahnya, yang dapat digunakan untuk melakukan diskusi kelas. Tampilan Quiz dapat dilihat pada Gambar 16.

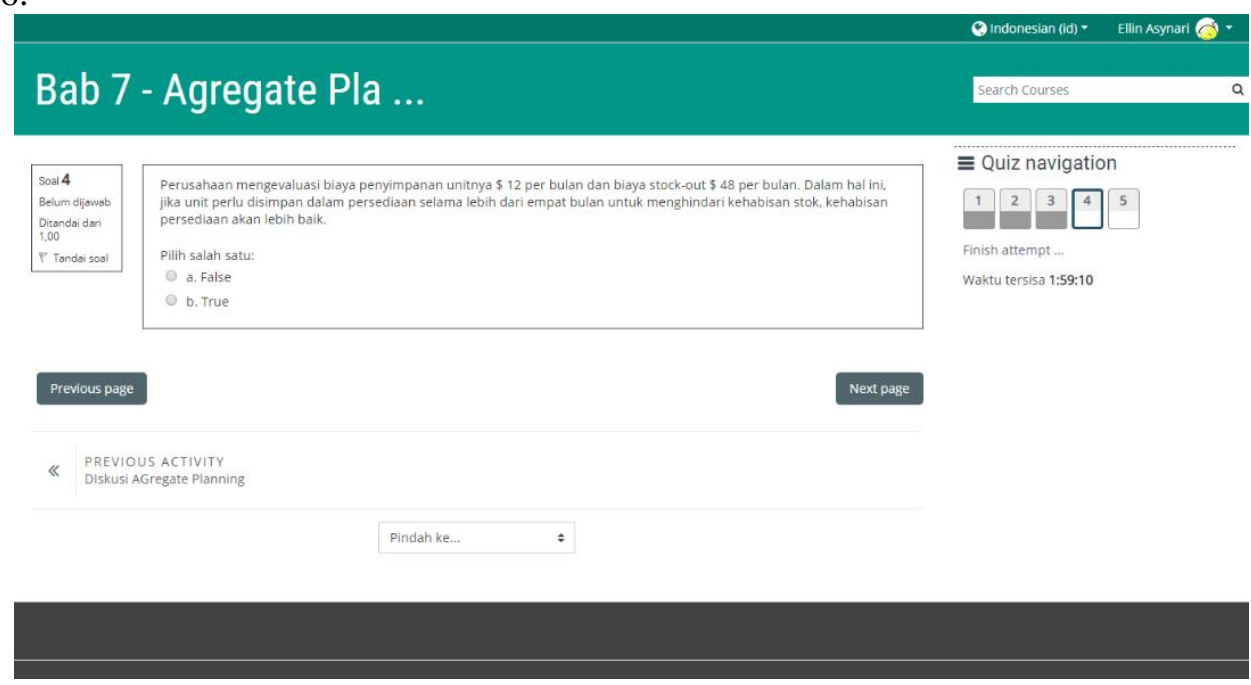

\section{Gambar 16. Tampilan Quiz}

i. Tampilan Notifikasi

Tampilan notifikasi berisi beberapa pengumuman penting atau notifikasi seperti deadline tugas, tugas baru, dan memulai kelas. Tapilan notifikasi dapat dilihat pada Gambar 17.

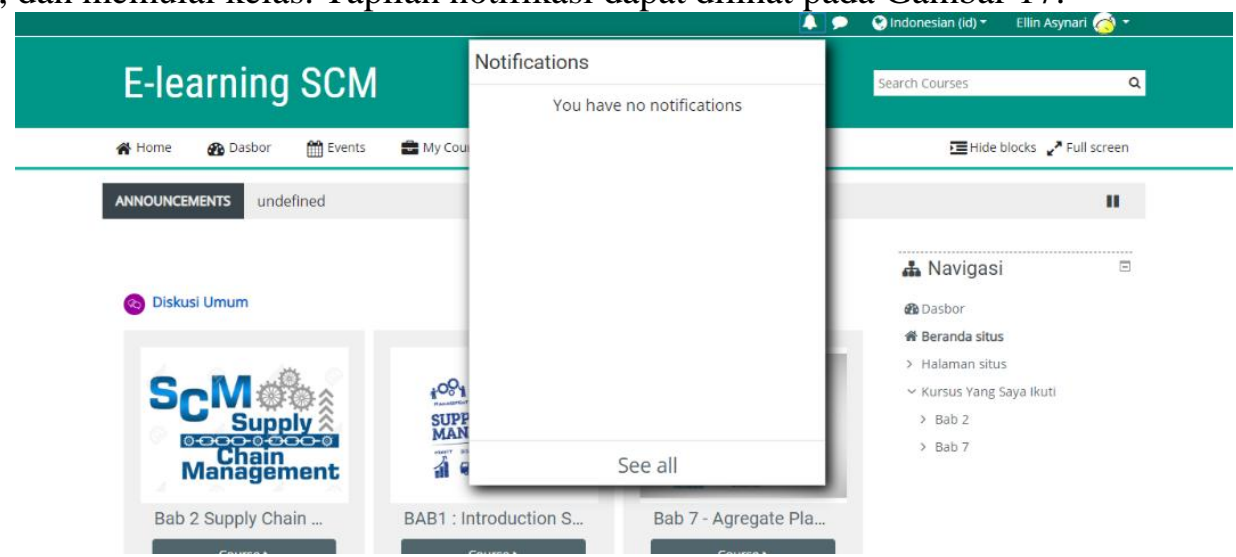

\section{Gambar 17. Tampilan Notifikasi}

j. Tampilan Chat

Tampilan chat merupakan tampilan pesan yang menempel pada jendela kanan, berisi pesan pesan yang dikirim atau di terima. Tampilan chat dapat dilihat pada Gambar 18.

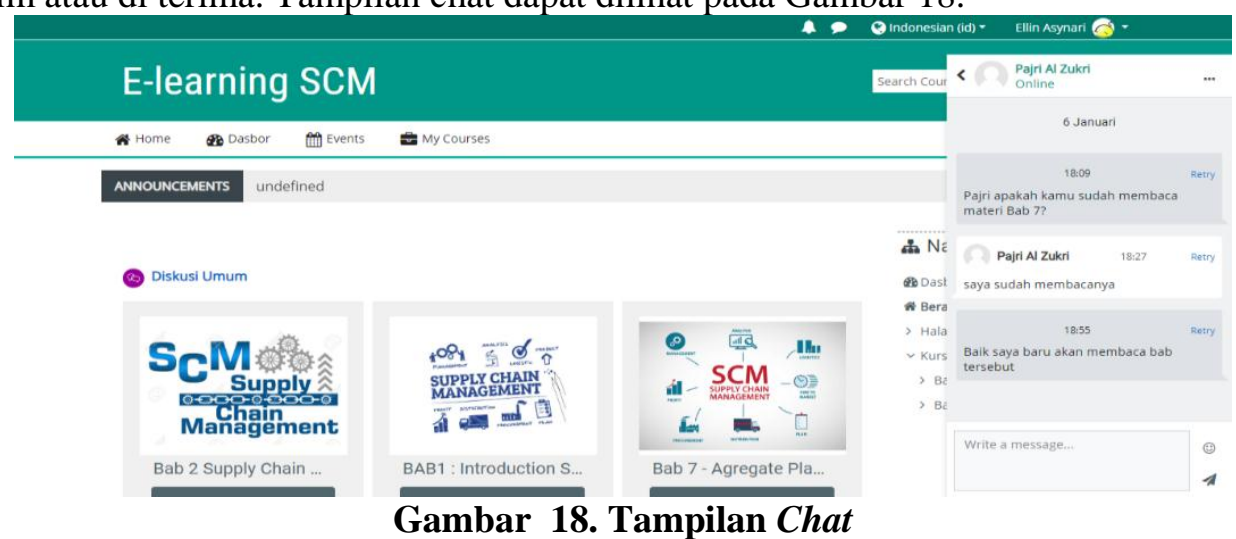

Ellin Asynari dkk : Standar Kelengkapan Fitur E-Learning Supply Chain Management Pada Produk Backlog Menggunakan Metodologi Scrum 


\section{k. Tampilan Bantuan}

Tampilan bantuan, merupakan tampilan yang menunjukkan tutorial atau step-step yang harus dilalui dalam menggunakan aplikasi. Tampilan bantuan dapat dilihat pada Gambar 19.

\section{KESIMPULAN}

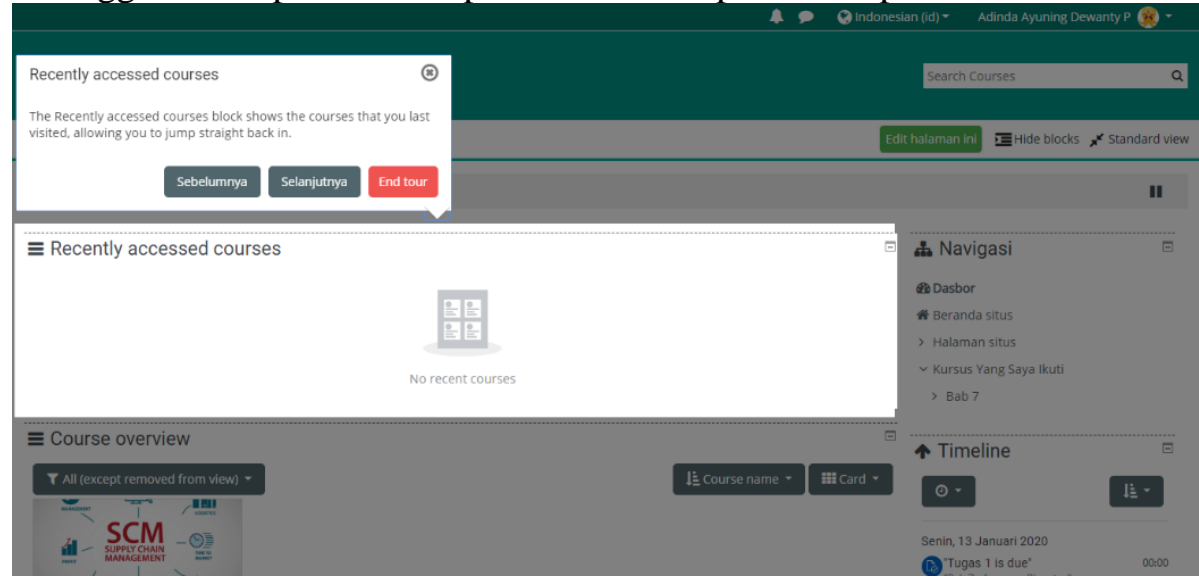

Gambar 19 Tampilan Bantuan

Dari hasil pembahasan sebelumnya yang dilakukan peneliti dapat disimpulkan bahwa dari tiga aplikasi e-learning yaitu aplikasi SEVIMA EdLink, Coursera, Blackboard CourseSites memiliki kelengkapan fitur yang berbeda-beda, dari masing-masing fitur di tiga aplikasi tersebut dapat dibuat backlog urutan fitur yang menjadi prioritas dalam pembuatan aplikasi e-learning. Prioritas fitur utama yang harus ada dalam aplikasi e-learning adalah fitur kelas dan yang menjadi prioritas terakhir dalam pembuatan aplikasi e-learning adalah fitur pengumuman. Standar pemilihan menggunakan metode SCRUM product backlog, dengan melakukan perbandingan antara masing-masing fitur dalam aplikasi e-learning SEVIMA EdLink, Coursera, Blackboard CourseSites dapat menjadi salah satu pilihan dalam melakukan analysis atau perancangan aplikasi e-learning dalam menentukan fitur-fitur apa saja yang dibutuhkan dalam sebuah aplikasi e-learning. Pembuatan prototype menggunakan Moodle, serta fitur-fitur yang ada di sesuaikan dengan hasil perbandingan sebelumnya.

Untuk penelitian selanjutnya, kami akan melakukan pengujian secara whiteboard dan blackboard kepada beberapa mahasiswa yang mengambil mata kuliah SCM. Penentuan standar kelengkapan fitur menggunakan metode SCRUM product backlog kedepannya dapat membandingkan beberapa fitur lain dalam aplikasi-aplikasi selain e-learning.

\section{REFERENSI}

[1] J. E. Lawrence and U. A. Tar, "Factors that influence teachers' adoption and integration of ICT in teaching/learning process," EMI. Educ. Media Int., vol. 55, no. 1, pp. 79-105, 2018.

[2] C. De Smet, M. Valcke, T. Schellens, B. De Wever, and R. Vanderlinde, "A qualitative study on learning and teaching with learning paths in a learning management system," J. Soc. Sci. Educ., vol. 15, no. 1, pp. 27-37, 2016.

[3] N. U. Ain, K. Kaur, and M. Waheed, "The influence of learning value on learning management system use: An extension of UTAUT2," Inf. Dev., vol. 32, no. 5, pp. 1306-1321, 2016.

[4] N. Islam, M. Beer, and F. Slack, "E-Learning Challenges Faced by Academics in Higher Education: A Literature Review," J. Educ. Train. Stud., vol. 3, no. 5, pp. 102-112, 2015.

[5] N. Shakhovska, V. Vysotska, and L. Chyrun, "Features of e-learning realization using virtual research laboratory," Comput. Sci. Inf. Technol. - Proc. 11th Int. Sci. Tech. Conf. CSIT 2016, pp. 143-148, 2016.

[6] K. L. Kumar and R. Owston, "Evaluating e-learning accessibility by automated and studentcentered methods," Educ. Technol. Res. Dev., vol. 64, no. 2, pp. 263-283, 2016.

[7] I. Kayes, M. Sarker, and J. Chakareski, "Product backlog rating: a case study on measuring test quality in scrum," Innov. Syst. Softw. Eng., vol. 12, no. 4, pp. 303-317, 2016.

[8] T. Sedano, P. Ralph, and C. Peraire, "The Product Backlog," Proc. - Int. Conf. Softw. Eng., vol. 2019-May, no. Section IV, pp. 200-211, 2019. 
[9] T. Makarchuk, V. Trofimov, and S. Demchenko, "Modeling The Life Cycle Of E-Learning Course Using Moodle Cloud Lms," in international scientific conference, 2019.

[10] B. Gros and F. J. García-peñalvo, "Future Trends in the Design Strategies and Technological Affordances of E-Learning," Learn. Des. Technol., pp. 1-23, 2019.

[11] B. Payne and T. Abegaz, "Gencyberscrum: improving cybersecurity education outcomes with the scrum framework," J. Comput. Sci. Coll., vol. 33, no. 4, pp. 60-68, 2018.

[12] Moodle.com, "Moodle LMS | Moodle," 2019. [Online]. Available: https://moodle.com/lms/. [Accessed: 06-Nov-2019].

[13] B. Pardoel and S. Papadima-, "CALLing all the CALLers Worldwide Moodle app gamification features and their potential for foreign language learning," no. September, 2019.

[14] M. Allen, Guides to E-Learning. 2016.

[15] M. Aparicio and F. Bacao, "E-learning concept trends," ACM Int. Conf. Proceeding Ser., no. July 2013, pp. 81-86, 2013.

[16] Nursalam and F. Efendi, Pendidikan Dalam Keperawatan Nursalam Ferry Efendi, no. March 2014. 2008.

[17] GoogleClassroom, "Kelas." [Online]. Available: https://classroom.google.com/u/0/h. [Accessed: 12-Dec-2019].

[18] D. Owens and G. Shekhar, "Using Scrum Princples to Transform the Classroom," in Twentyfourth Americas Conference on Information Systems, New Orleans, 2018, 2018, p. 2018.

[19] F. M. Fowler and F. M. Fowler, "What Is Scrum?," Navig. Hybrid Scrum Environ., pp. 3-8, 2019.

[20] Ifra and J. K. Bajwa, "Metrics of Scrum Methodology," Int. J. Comput. Appl., vol. 149, no. 2, pp. 975-8887, 2016.

[21] AgileCampus.org, "Apa itu Product Backlog? - AgileCampus.org," 2019. [Online]. Available: https://www.agilecampus.org/apa-itu-product-backlog. [Accessed: 29-Nov-2019].

[22] H. Stadtler, "Supply chain management - An overview," Supply Chain Manag. Adv. Plan. (Fourth Ed. Concepts, Model. Software, Case Stud., pp. 9-36, 2008.

[23] P. Zaharias and C. Pappas, "Quality Management of Learning Management Systems: A User Experience Perspective," Curr. Issues Emerg. eLearning, vol. 3, no. 1, pp. 60-83, 2016.

[24] eLearning Industry, "What Is A Learning Management System? LMS Basic Functions And Features You Must Know (2019 Update) - eLearning Industry." [Online]. Available: https://elearningindustry.com/what-is-an-lms-learning-management-system-basic-functionsfeatures. [Accessed: 12-Dec-2019].

[25] G. C. Oproiu, "A Study about Using E-learning Platform (Moodle) in University Teaching Process," Procedia - Soc. Behav. Sci., vol. 180, no. November 2014, pp. 426-432, 2015.

[26] K. C. Deepak, "Evaluation of Moodle Features at Kajaani University of Applied SciencesCase Study," Procedia Comput. Sci., vol. 116, pp. 121-128, 2017.

[27] M. Vaismoradi, J. Jones, H. Turunen, and S. Snelgrove, "Theme development in qualitative content analysis and thematic analysis," J. Nurs. Educ. Pract., vol. 6, no. 5, 2016. 